\title{
Selectively electrochemical generation of hydrogen peroxide from oxygen reduction on atomically dispersed platinum
}

Yun-Chao Yin, Yi Shi, Yi-Bai Sun, Dong-Rui Yang, Yang Liu, Xing-Hua Xia*

State Key Laboratory of Analytical Chemistry for Life Science, School of Chemistry and Chemical Engineering, Nanjing University, Nanjing 210023, China

*To whom correspondence should be addressed to: X. H. Xia (xhxia@nju.edu.cn) 


\section{Methods}

\section{Preparation of catalysts}

Meso-S-C. The $2.0 \mathrm{~g} \mathrm{2,2'-bithiophene} \mathrm{and} 1.0 \mathrm{~g} \mathrm{Co}\left(\mathrm{NO}_{3}\right)_{2} \cdot 6 \mathrm{H}_{2} \mathrm{O}$ were mixed into $120 \mathrm{~mL}$ tetrahydrofuran. Then, $2.0 \mathrm{~g} \mathrm{SiO}_{2}$ fumed powder was mixed with the above solution and stirred for $6 \mathrm{~h}$. After evaporation of tetrahydrofuran, the powder was carbonized at $800{ }^{\circ} \mathrm{C}$ under Ar for $2 \mathrm{~h}$. The $\mathrm{SiO}_{2}$ template was etched in $\mathrm{NaOH}(2.0 \mathrm{M})$ for 3 days and the cobalt was removed by $\mathrm{H}_{2} \mathrm{SO}_{4}$ at $90{ }^{\circ} \mathrm{C}$ for $4 \mathrm{~h}$.

\section{Scale-up production of Pt-meso-S-C}

The scale-up production of Pt-meso-S-C was prepared in an H-cell which contains a cathodic chamber and anodic chamber separated by a Nafion 115 . The three-electrode cell configuration was used. The working electrode (a graphite rod) and reference electrode(saturated $\mathrm{Ag} / \mathrm{AgCl}$ ) were arranged in the cathodic chamber filled with $0.1 \mathrm{M} \mathrm{H}_{2} \mathrm{SO}_{4}+2 \mathrm{mM} \mathrm{CuSO}_{4}$ and meso-S-C, while the Pt net was inserted in the anodic half-cell to avoid the re-oxidation of the products. A constant potential $(0.1 \mathrm{~V}$ vs $\mathrm{Ag} / \mathrm{AgCl})$ was then set to underpotential deposition of $\mathrm{Cu}$ adatoms. Then, a solution of $0.1 \mathrm{M} \mathrm{K}_{2} \mathrm{PtCl}_{4}$ or $0.9 \mathrm{M} \mathrm{K}_{2} \mathrm{PtCl}_{4}$ ) was injected into the cathodic cell. The resultant product was collected. All the solutions were purged with Ar thoroughly to prevent the oxidation of $\mathrm{Cu}$ adatoms in contact with $\mathrm{O}_{2}$.

Physical characterizations. The morphologies of each sample were characterized on a TEM (JEOL JEM-2100, Japan). The aberration-corrected HAADF-STEM analysis was performed on a FEI Titan ${ }^{3}$ G2 60-300 system. The samples were texted by XRD (D8). The XPS were texted on a PHI 5000 VersaProbe (Japan). All the binding energies reported here were calibrated by the C 1s peak energy of $284.5 \mathrm{eV}$.

Electrochemical measurements. The RDE (glassy carbon) experiments were performed using an electrochemical workstation (CHI900) at ambient temperature. ORR text was conducted in $0.1 \mathrm{M} \mathrm{HClO}_{4}(\mathrm{pH}=1)$ which was purged with $\mathrm{O}_{2}$ during the measurement. $2.5 \mathrm{mg}$ of sample was added into $25 \mu \mathrm{L}$ of $5 \% \mathrm{wt}$ Nafion and 975 $\mu \mathrm{L}$ isopropanol, followed by $30 \mathrm{~min}$ sonication to get a homogeneous ink. After, 10 $\mu \mathrm{L}$ of the catalyst ink was coated on the polished disk surface of RDE. The modified 
RDE was used as the working electrode.

The Koutecky-Levich (K-L) plots reflecting the relation of current density $\left(I^{-1}\right)$ versus rotation rate $\left(\omega^{-1 / 2}\right)$ were constructed according to

$$
\begin{aligned}
& \frac{1}{I}=\frac{1}{I_{k}}+\frac{1}{I_{d}} \\
& I_{d}=0.62 n F A D^{2 / 3} v^{-1 / 6} \omega^{1 / 2} C_{O_{2}}
\end{aligned}
$$

$I$ is the measured current, $I_{\mathrm{d}}$ is the diffusion-limiting current. $D_{\mathrm{O} 2}$ denotes the diffusion coefficient of $\mathrm{O}_{2}\left(1.93 \times 10^{-5}\right) . F=96485 \mathrm{C} \mathrm{mol}^{-1} \cdot \mathrm{C}_{\mathrm{O}_{2}}$ is the concentration of molecular oxygen in $0.1 \mathrm{M} \mathrm{HClO}_{4}$ solution $\left(1.26 \times 10^{-6} \mathrm{~mol} / \mathrm{cm}^{3}\right) . v$ is the kinematic viscosity of the electrolyte $\left(1.01 \times 10^{-2} \mathrm{~cm}^{2} / \mathrm{s}^{1}\right) . \omega$ is the angular velocity. The polarization curves of the ORR were measured with a series of rotation speeds (400, 625, 900, 1225 and $1600 \mathrm{rpm})$. The background current was measured in $\mathrm{N}_{2}-0.1 \mathrm{M} \mathrm{HClO}_{4}$.

The polarization curve of PRR was measured in a $\mathrm{N}_{2}$-saturated solution of $0.1 \mathrm{M}$ $\mathrm{HClO}_{4}+10 \mathrm{mM} \mathrm{H}_{2} \mathrm{O}_{2}$ at $1600 \mathrm{rpm}$. Chronoamperometric measurement was used to survey the stability of Pt1-meso-S-C at $0.235 \mathrm{~V}$ at $1600 \mathrm{rpm}$.

The electrocatalytic $\mathrm{H}_{2} \mathrm{O}_{2}$ production was operated in a H-cell with a Nafion 115 separating the cathodic and anodic chambers. The working electrode was prepared by depositing Pt1-meso-S-C catalyst ink $(200 \mu \mathrm{L})$ on a carbon paper $\left(1 \mathrm{x} 1 \mathrm{~cm}^{2}\right)$. Before the electrochemical $\mathrm{H}_{2} \mathrm{O}_{2}$ production test, a flow of high-purity $\mathrm{O}_{2}$ and $\mathrm{H}_{2}$ gases was purged into the anode and cathode chambers for $30 \mathrm{~min}$, respectively. Then, the $\mathrm{H}$-cell was operated at the $0.097 \mathrm{~V}$ under the room temperature. The $\mathrm{H}_{2} \mathrm{O}_{2}$ concentration was determined by the titration method with potassium permanganate. 


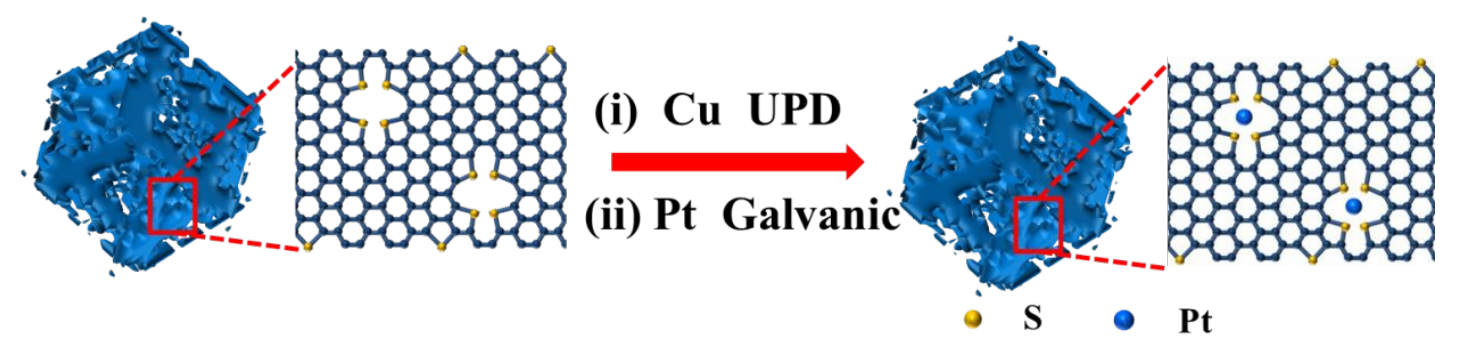

Figure S1. Schematic illustration of the catalyst preparation process.
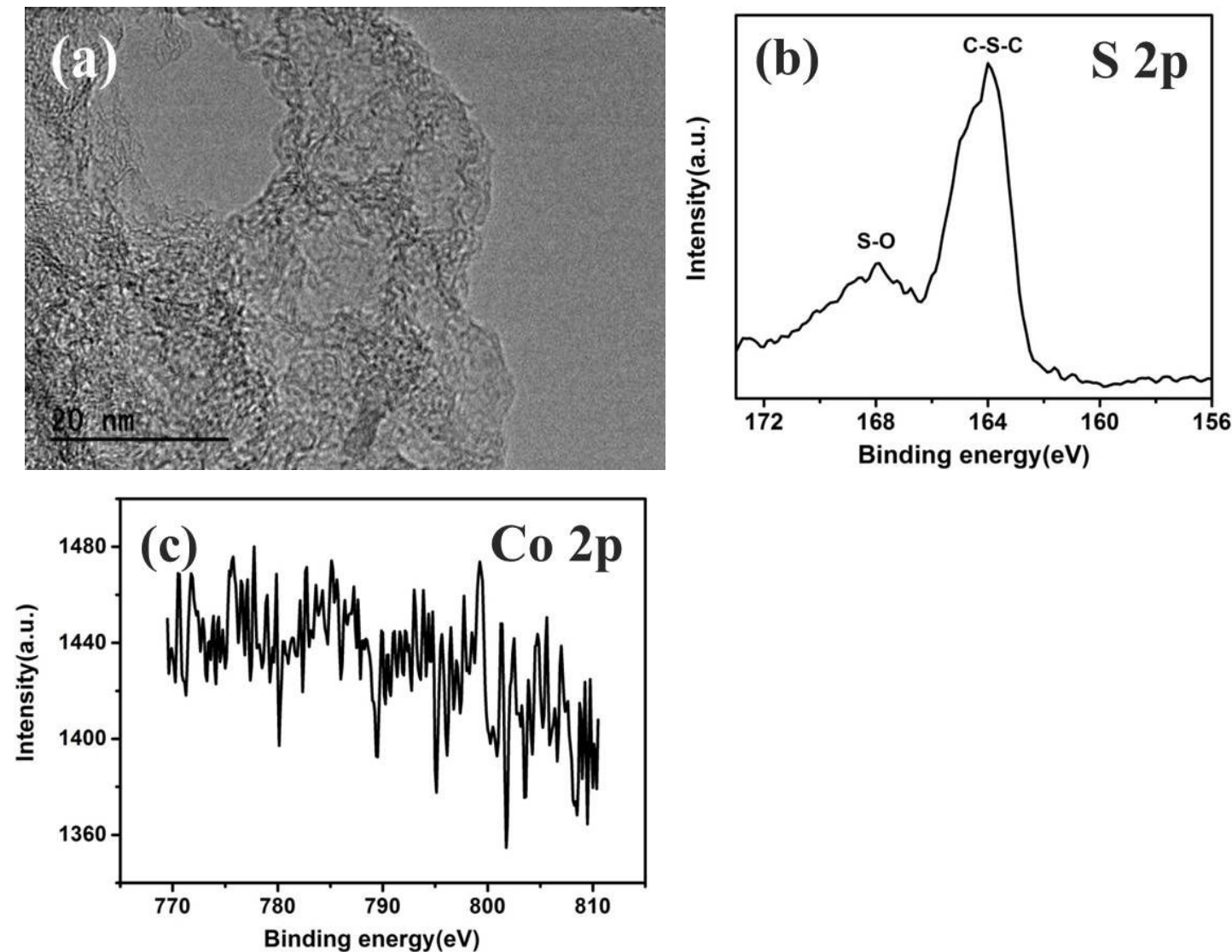

Figure S2. Characterizations of meso-S-C. (a) the TEM image (b) the meso-S-C XPS-S $2 p$ spectra (c) the meso-S-C XPS-Co $2 p$ spectra. 

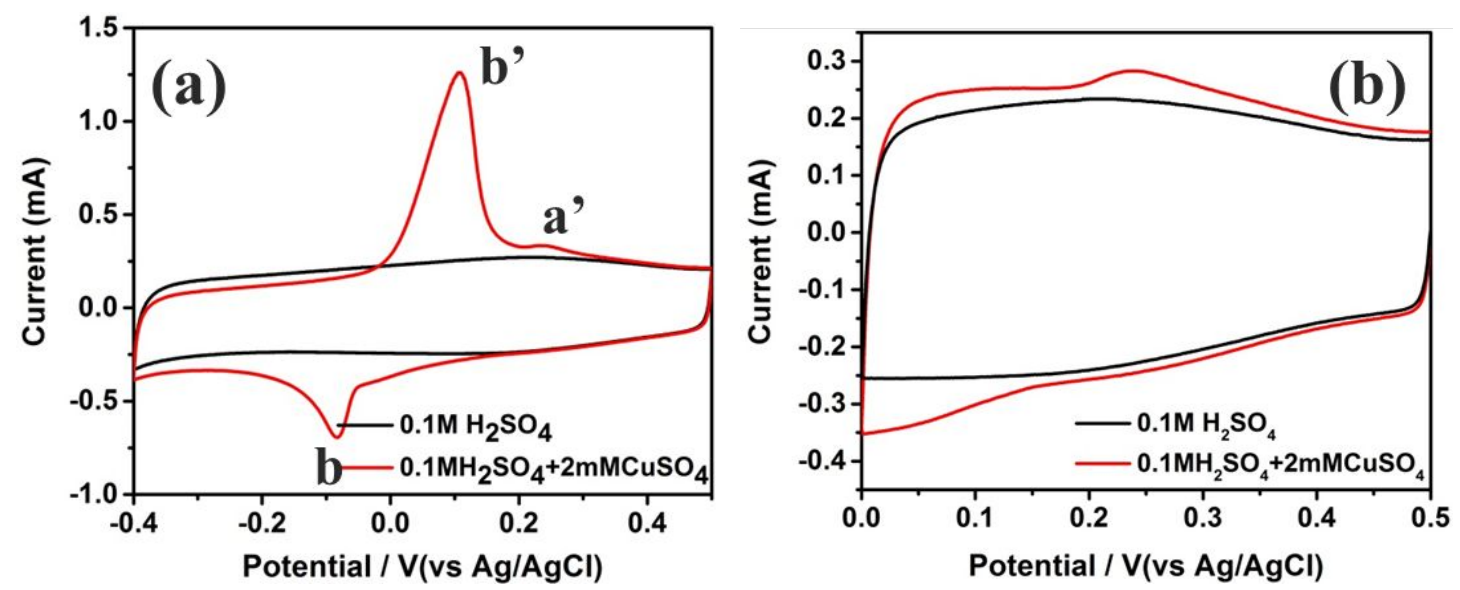

Figure S3. (a) CVs of meso-S-C on a GC electrode in $0.1 \mathrm{M} \mathrm{H}_{2} \mathrm{SO}_{4}$ and $0.1 \mathrm{M}$ $\mathrm{H}_{2} \mathrm{SO}_{4}+2 \mathrm{mM} \mathrm{CuSO}_{4}$ solution. (b) $\mathrm{CVs}$ of the same electrode in the potential widow of UPD in the same solution.
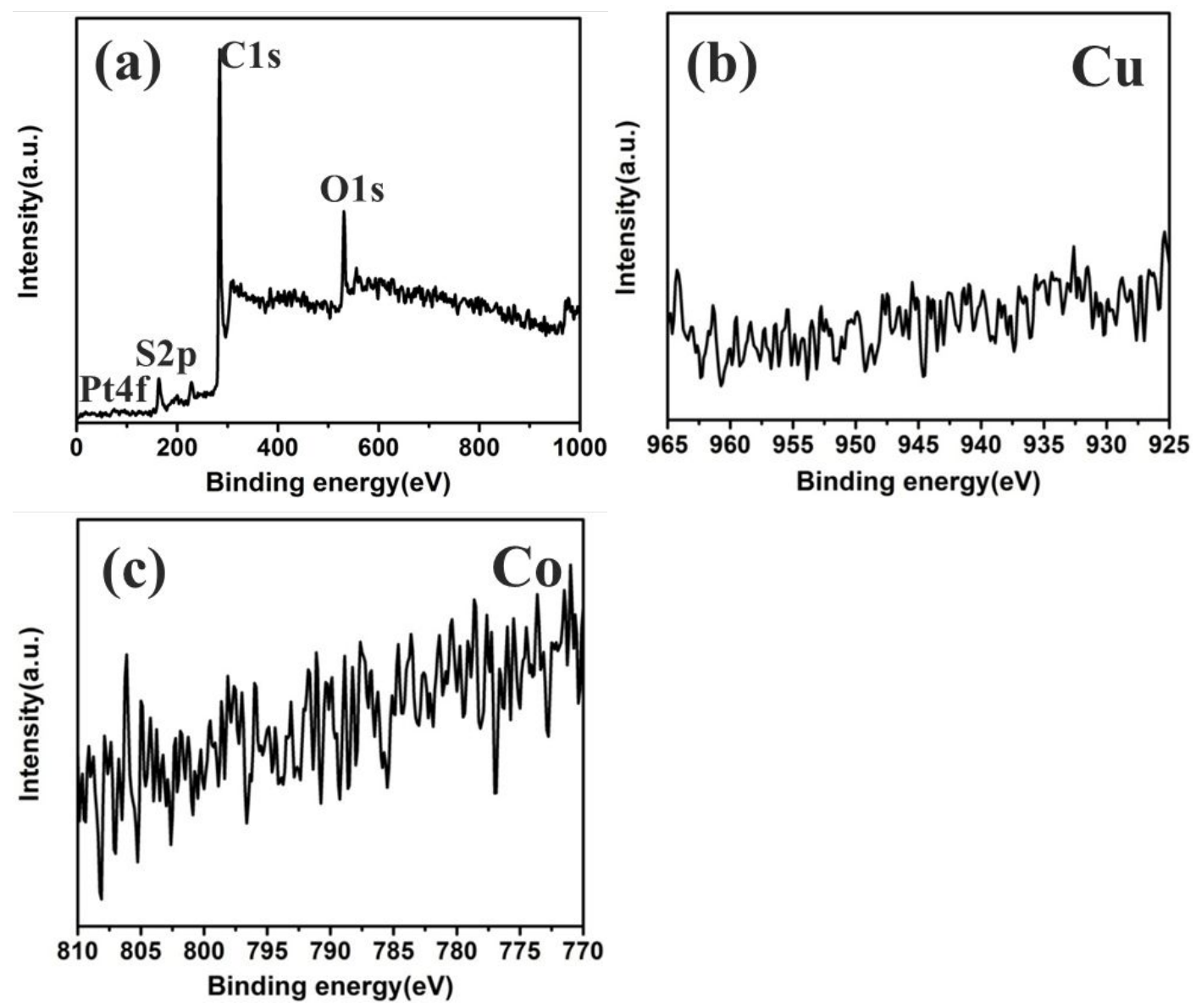

Figure S4. (a) XPS spectrum of the Pt1-meso-S-C sample. XPS survey spectra of $\mathrm{Cu}$ $2 p(\mathrm{a})$ and Co $2 p(\mathrm{~b})$. 

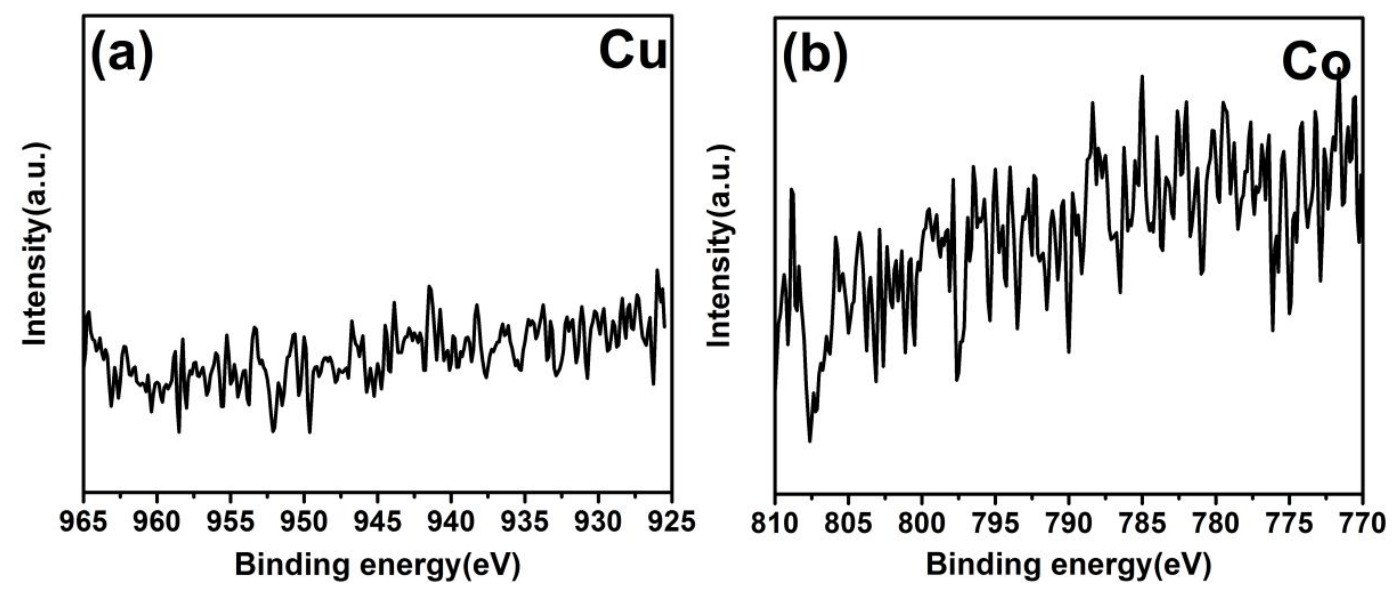

Figure S5. XPS survey spectra of $\mathrm{Cu} 2 p$ (a) and $\mathrm{Co} 2 p$ (b) of the Ptn-meso-S-C sample.
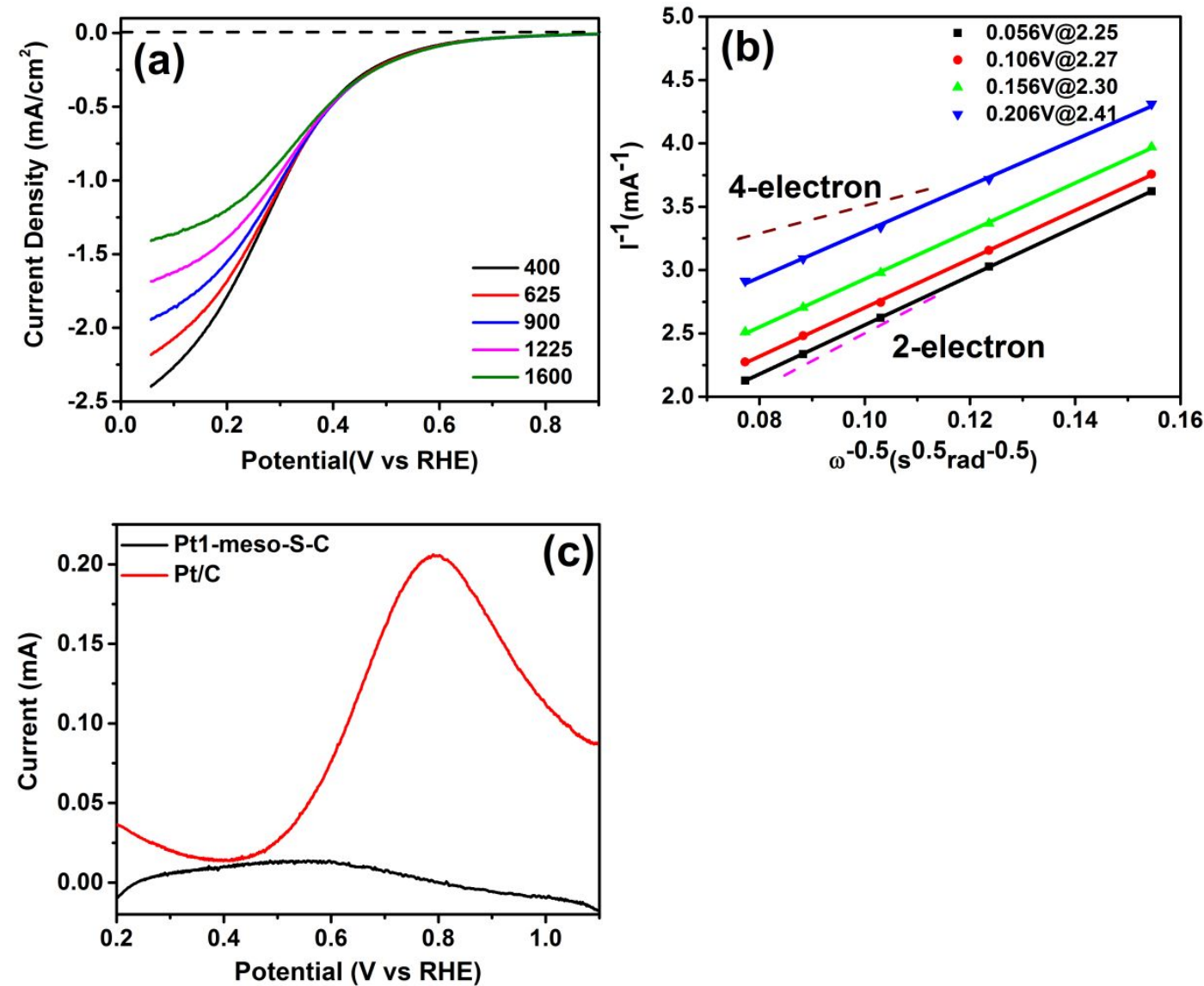

Figure S6. (a) RDE voltammograms of Ptn-meso-S-C at different rotating rates from 400 to $1600 \mathrm{rpm}$ in an $\mathrm{O}_{2}$-saturated solution of $0.1 \mathrm{M} \mathrm{HClO}_{4}$. (b) Corresponding K-L plots at different potentials. (c) CVs of Pt1-meso-S-C (black curve) and commercial $\mathrm{Pt} / \mathrm{C}$ catalysts in a $\mathrm{N}_{2}$-saturated solution of $0.1 \mathrm{M} \mathrm{HClO}_{4}+25 \mathrm{mM}$ methanol at a scan rate of $50 \mathrm{mV} / \mathrm{s}$. 


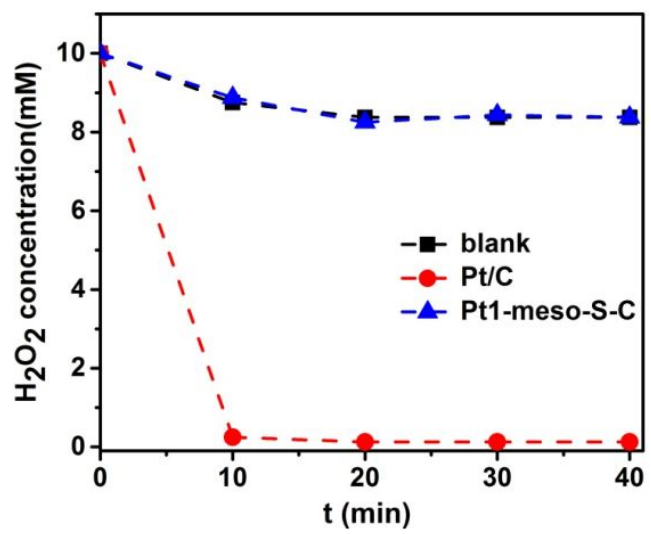

Figure S7. PDR activities derived from the decline in $\mathrm{H}_{2} \mathrm{O}_{2}$ concentration in a $10 \mathrm{mM}$ $\mathrm{H}_{2} \mathrm{O}_{2}+0.1 \mathrm{M} \mathrm{HClO}_{4}$ starting solution $(10 \mathrm{~mL})$ containing $2 \mathrm{mg}$ catalysts. For comparison, the PDR of a blank solution without catalyst was also investigated. 